Supplement of Biogeosciences, 17, 5539-5561, 2020

https://doi.org/10.5194/bg-17-5539-2020-supplement

(C) Author(s) 2020. This work is distributed under

the Creative Commons Attribution 4.0 License.

(c) (1)

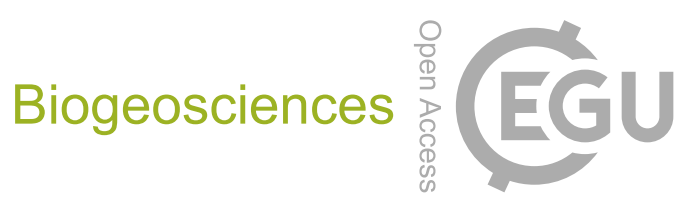

Supplement of

\title{
Particulate rare earth element behavior in the North Atlantic (GEOVIDE cruise)
}

\section{Marion Lagarde et al.}

Correspondence to: Marion Lagarde (marion.lagarde@legos.obs-mip.fr)

The copyright of individual parts of the supplement might differ from the CC BY 4.0 License. 
Particulate Rare Earth Element behavior in the North Atlantic (GEOVIDE cruise): supplementary material

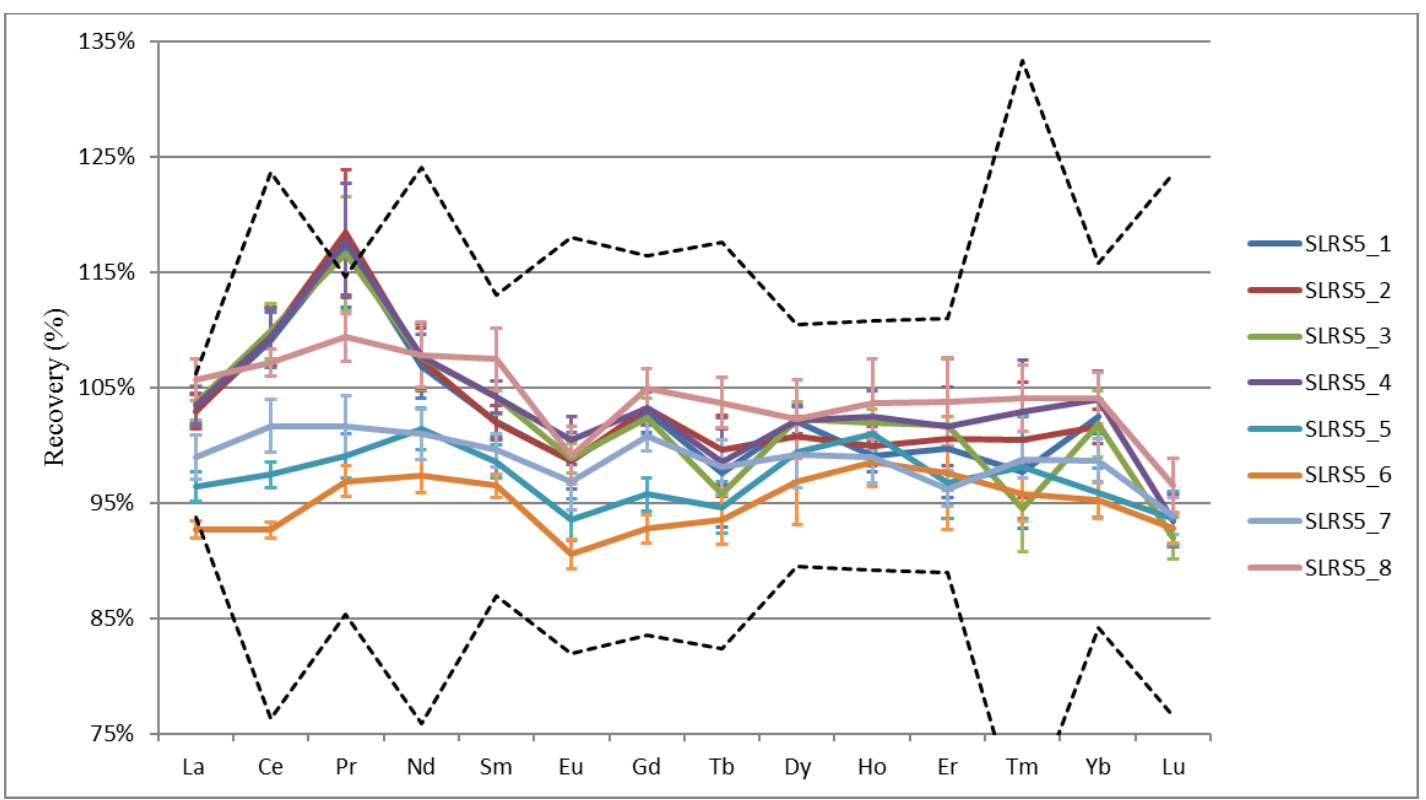

Figure S1: Percentage of recovery of the CRM SLRS-5 analyzed concomitantly with the samples of the study. The dotted lines bracket the consensual range from (Yeghicheyan et al., 2013).

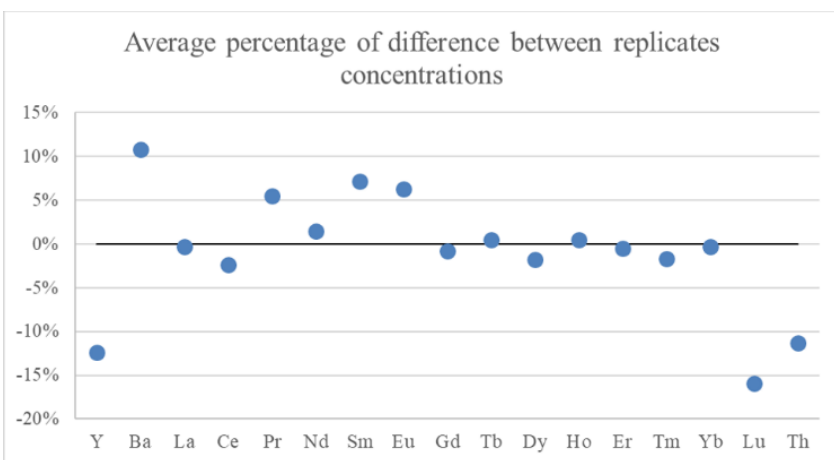

Figure S2: Average percentage of difference between concentrations measured two times in the same sample, per element, $\mathbf{n}=\mathbf{2 3}$.

\begin{tabular}{|l|l|c|}
\hline Source of error & Determination & $\begin{array}{c}\text { Mean } \% \text { of the } \\
\text { concentration }\end{array}$ \\
\hline Volume of leachate & $\begin{array}{l}\text { 2sd calculated on the weight of all archive } \\
\text { volume after } 13 \mathrm{~mL} \text { of } \mathrm{HNO} 30.32 \mathrm{M} \text { were added }\end{array}$ & $0.6 \%$ \\
\hline $\begin{array}{l}\text { Volume taken for ICP-MS } \\
\text { analysis }\end{array}$ & $\begin{array}{l}\text { Average 2sd calculated on weight replicates for } \\
\text { a sample }\end{array}$ & $0.005 \%$ \\
\hline ICP-MS measurement & $\begin{array}{l}\text { 2sd calculated on 5 spectra measured for a } \\
\text { sample }\end{array}$ & $3.3 \%$ \\
\hline
\end{tabular}

Figure S3: Averaged error on concentration ratio for each source of error 
A

\begin{tabular}{|c|c|c|c|}
\hline Sampling system & Leaching & Element & Place of measurement \\
\hline \multirow{2}{*}{ GO-FLO bottles } & \multirow{2}{*}{$\begin{array}{c}\mathrm{HNO} 3+\mathrm{HF} 4 \mathrm{~h} \\
\text { at } 130^{\circ} \mathrm{C}\end{array}$} & $\mathrm{Ba}$ & Brest \\
\hline & & Y & Brest \\
\hline \multirow{3}{*}{ Niskin bottle } & \multirow{3}{*}{$\begin{array}{c}\mathrm{HCl}+\mathrm{HNO}^{+}+ \\
\mathrm{HF} \text { overnight } \\
\text { at } 90^{\circ} \mathrm{C}\end{array}$} & $\mathrm{Ba}$ & Tervuren and Toulouse \\
\hline & & Th & Tervuren and Toulouse \\
\hline & & $Y$ & Toulouse \\
\hline
\end{tabular}

C

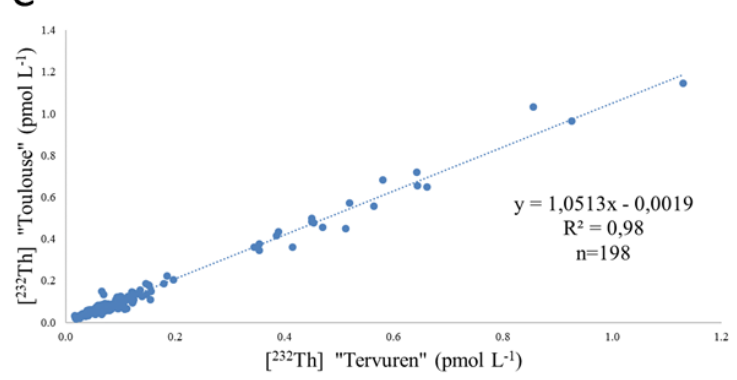

B

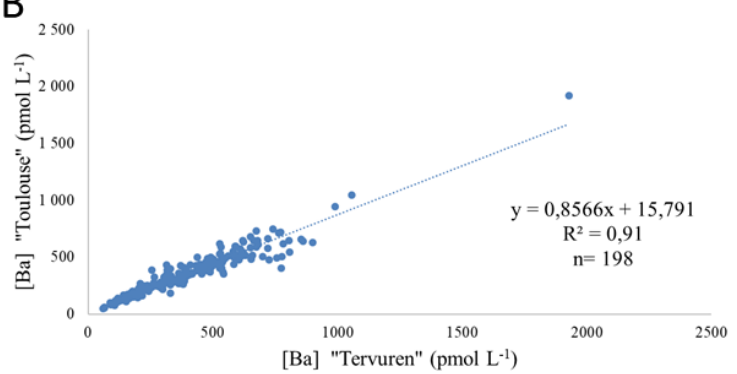

D

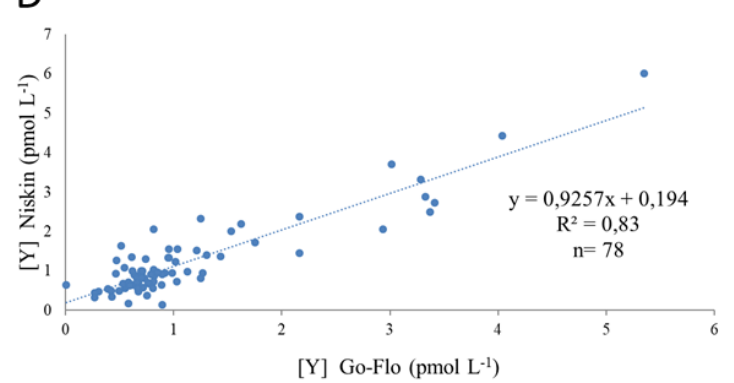

Figure S4: A. Summary of the differences between sampling systems and analytical protocols. B. Comparisons of Ba concentrations (pmol $\mathrm{L}^{-1}$ ) measured in the same samples at Tervuren and at Toulouse. and C. Comparisons of ${ }^{232} \mathrm{Th}$ concentrations (pmol $\mathrm{L}^{-1}$ ) measured in the same samples at Tervuren and at Toulouse. D. Comparison of $Y$ concentrations in particles collected with Niskin bottles analyzed in Toulouse and GO-FLO bottles analyzed in LEMAR.

\begin{tabular}{|c|c|c|c|c|c|}
\hline Reference & Location & Sampling method & $\begin{array}{l}\mathrm{Nd} \\
(\mathrm{pmol} \mathrm{L}-1)\end{array}$ & $\begin{array}{l}\mathrm{Ce} \\
(\mathrm{pmol} \mathrm{L}-1)\end{array}$ & $\begin{array}{l}\mathrm{Yb} \\
(\mathrm{pmol} \mathrm{L}-1)\end{array}$ \\
\hline $\begin{array}{l}\text { Kuss et al. } \\
(2001)\end{array}$ & $\begin{array}{l}\text { Along the } \\
20^{\circ} \mathrm{W} \text { meridian } \\
\text { between } 30^{\circ} \mathrm{N} \\
\text { and } 60^{\circ} \mathrm{N}\end{array}$ & $\begin{array}{l}\text { Samples pumped and } \\
\text { centrifuged from } \\
\text { several } \mathrm{m}^{3} \text { of } \\
\text { water at a depth of } 7 \mathrm{~m} \\
(\mathrm{n}=24)\end{array}$ & $\begin{array}{l}0.17 \text { to } 2.16 \\
\text { Average } 0.67\end{array}$ & $\begin{array}{l}0.2 \text { to } 4.9 \\
\text { Average } 0.82\end{array}$ & $\begin{array}{l}0.03 \text { to } 0.47 \\
\text { Average } 0.13\end{array}$ \\
\hline $\begin{array}{l}\text { Tachikawa } \\
\text { et al. (1999) }\end{array}$ & $\begin{array}{l}\text { Tropical } \\
\text { northeastern } \\
\text { Atlantic }\left(20^{\circ} \mathrm{N},\right. \\
\left.18-31^{\circ} \mathrm{W}\right)\end{array}$ & $\begin{array}{l}\text { In-situ pumps at } 3 \\
\text { stations (an eutrophic } \\
\text { (E), a mesotrophic (M) } \\
\text { and an oligotrophic (O) } \\
\text { sites), filtration of } 30 \text { to } \\
995 \mathrm{~L}\end{array}$ & $\begin{array}{l}E: 0.7 \text { to } 10.5 \\
M: 0.3 \text { to } 2.6 \\
\text { O: } 0.1 \text { to } 0.5\end{array}$ & $\begin{array}{l}E: 2.5 \text { to } 24.6 \\
M: 1.0 \text { to } 5.5 \\
O: 0.4 \text { to } 1.1\end{array}$ & $\begin{array}{l}\text { E: } 0.04 \text { to } 0.5 \\
M: 0.02 \text { to } 0.09 \\
\text { O: } 0.05 \text { to } 0.03\end{array}$ \\
\hline This study & $\begin{array}{l}\text { Subpolar North } \\
\text { Atlantic (40- } \\
\left.60^{\circ} \mathrm{N}, 10-55^{\circ} \mathrm{W}\right)\end{array}$ & Niskin bottles & 0.1 to 6.1 & 0.2 to 16.3 & 0.01 to 0.50 \\
\hline
\end{tabular}

Figure S5: Comparison of PREE available data in the North Atlantic, including this publication. Data from (Kuss et al., 2001; Tachikawa et al., 1999) 


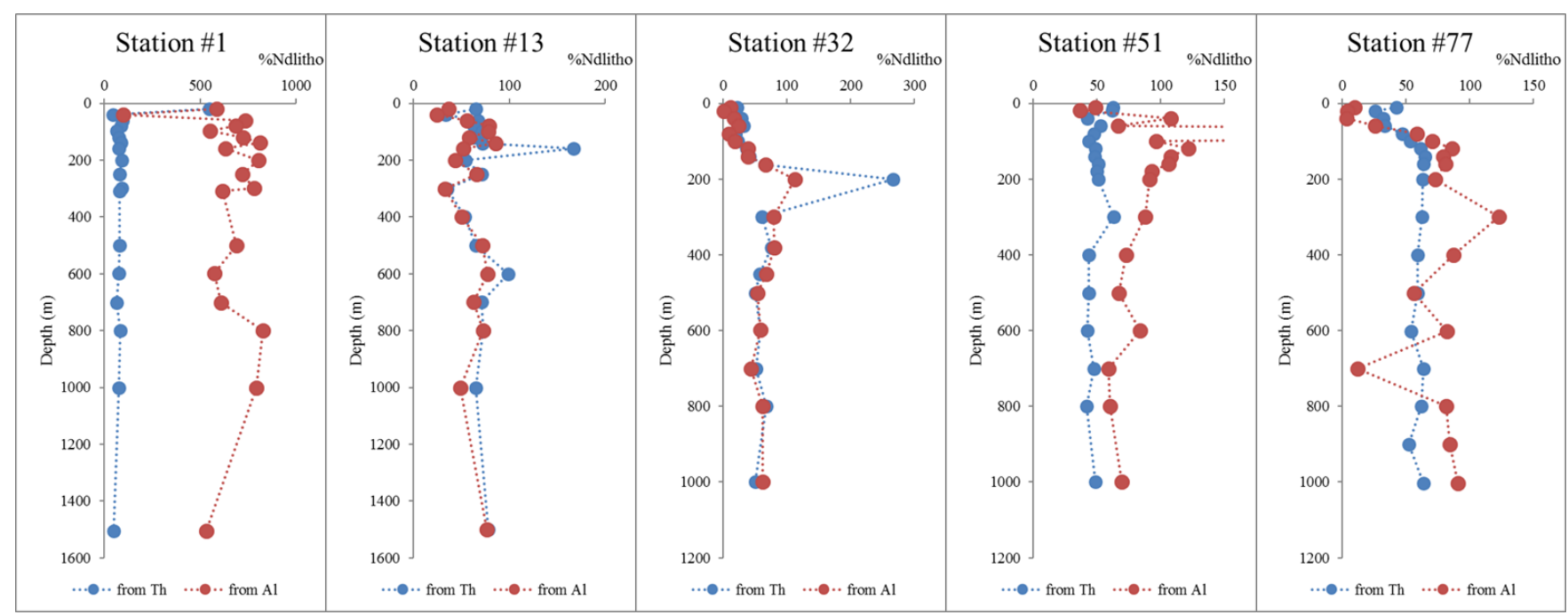

Fig. S6 Comparison of lithogenic fractions calculated from ${ }^{232} \mathrm{Th}$ (in blue) and Al at different stations (in red, data from (Gourain et al., 2019) 


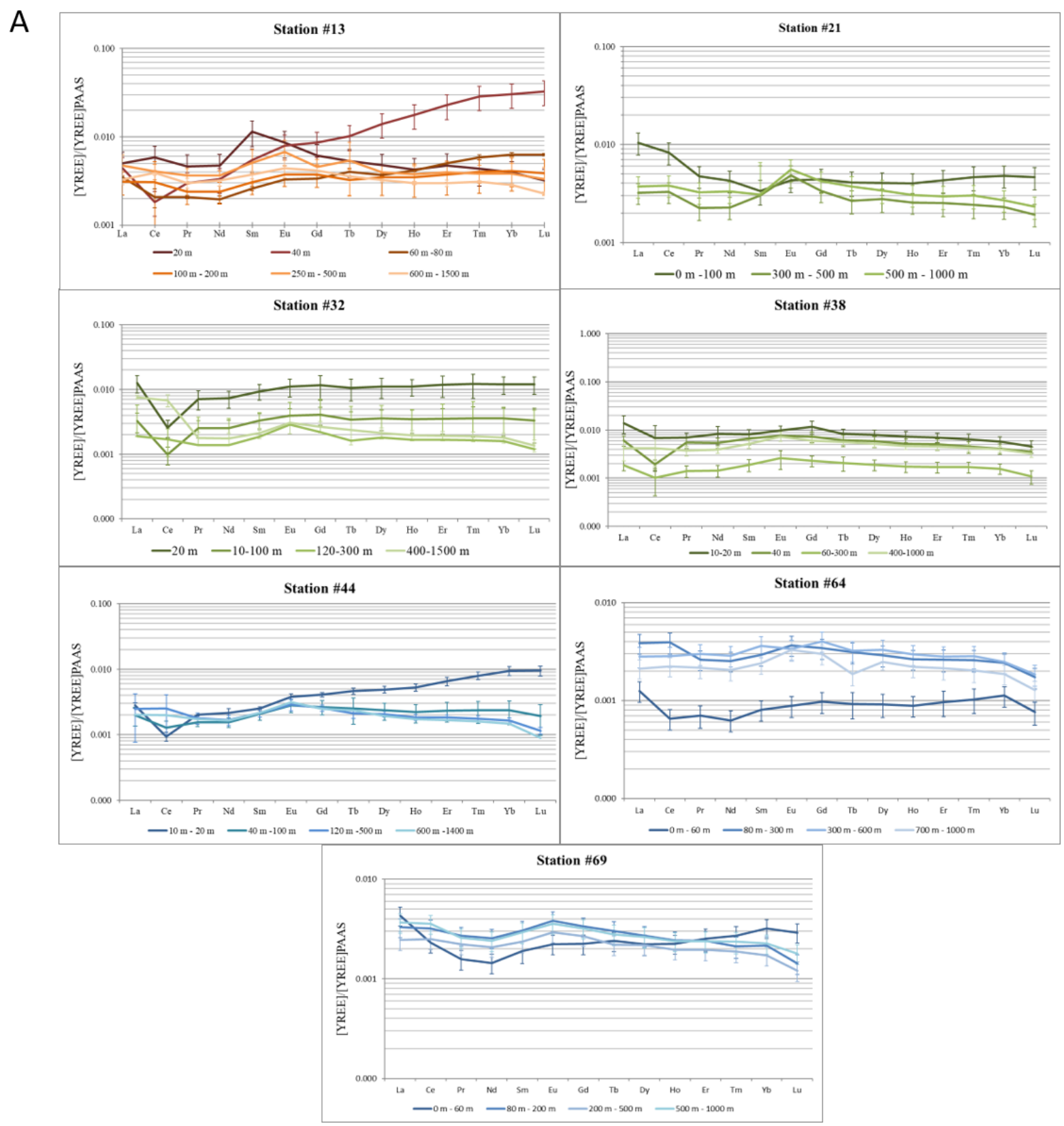




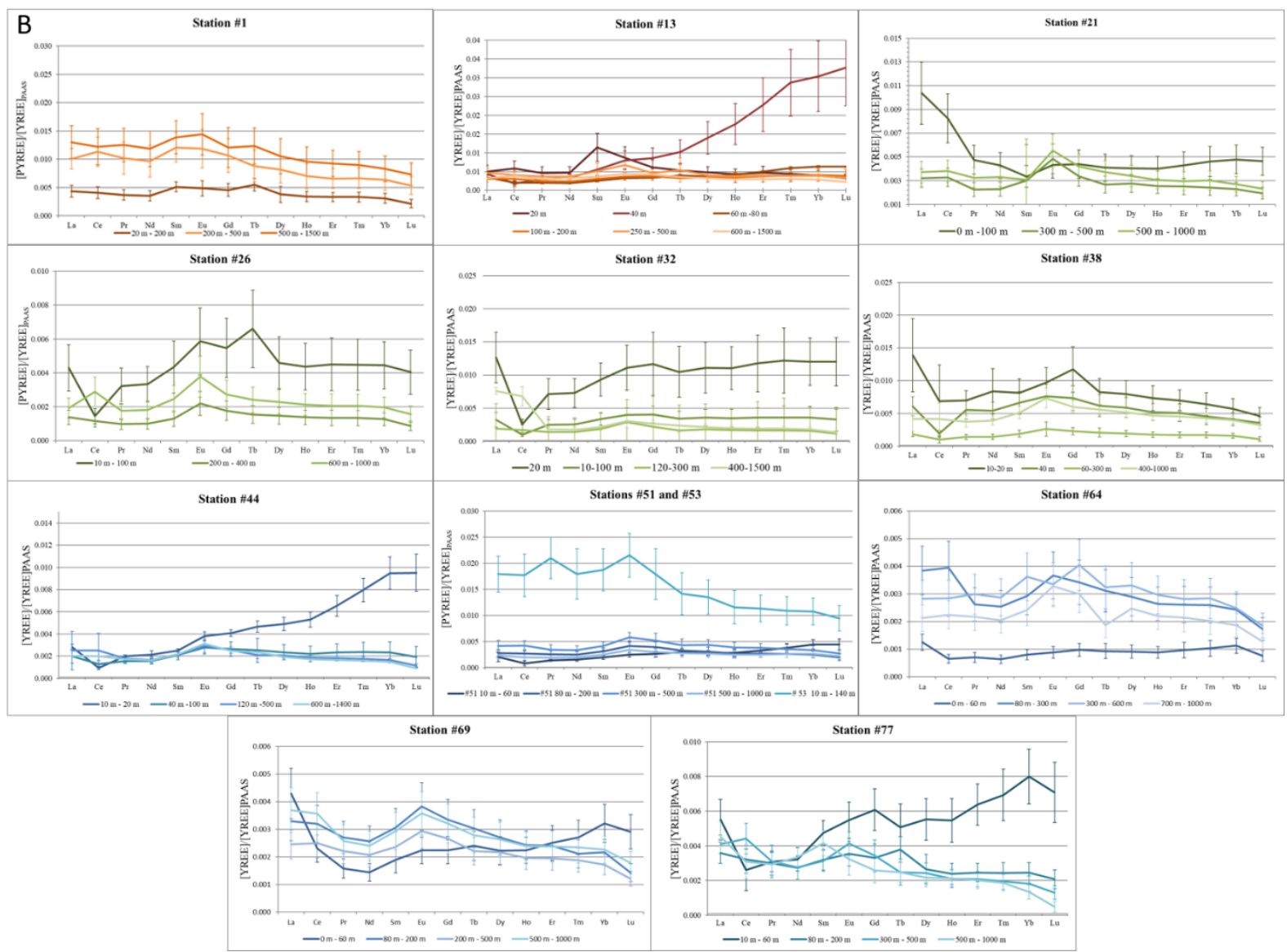

Figure S7: A. PAAS-normalized REE patterns of the total fraction, averaged at several depths and depth layers, at stations \#13, \#21, \#32, \#38, \#44, \#64 and \#69 and B. REE patterns averaged at several depths and depth layers at all stations.

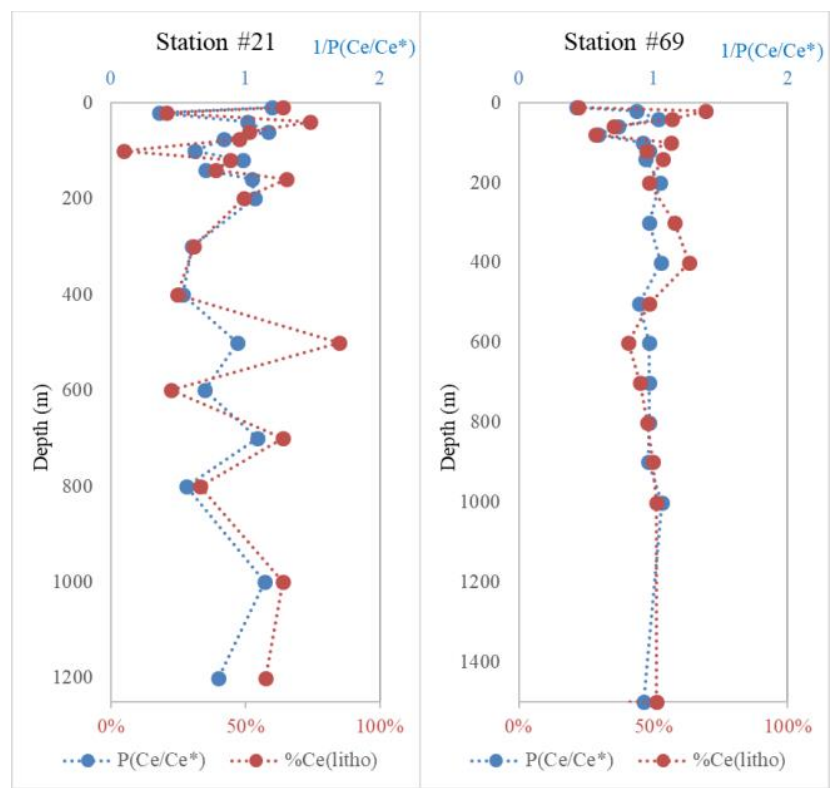

Figure S8: Vertical profiles of 1/PCe anomalies and Ce lithogenic contributions (in \%)at stations \#21 and \#69. 


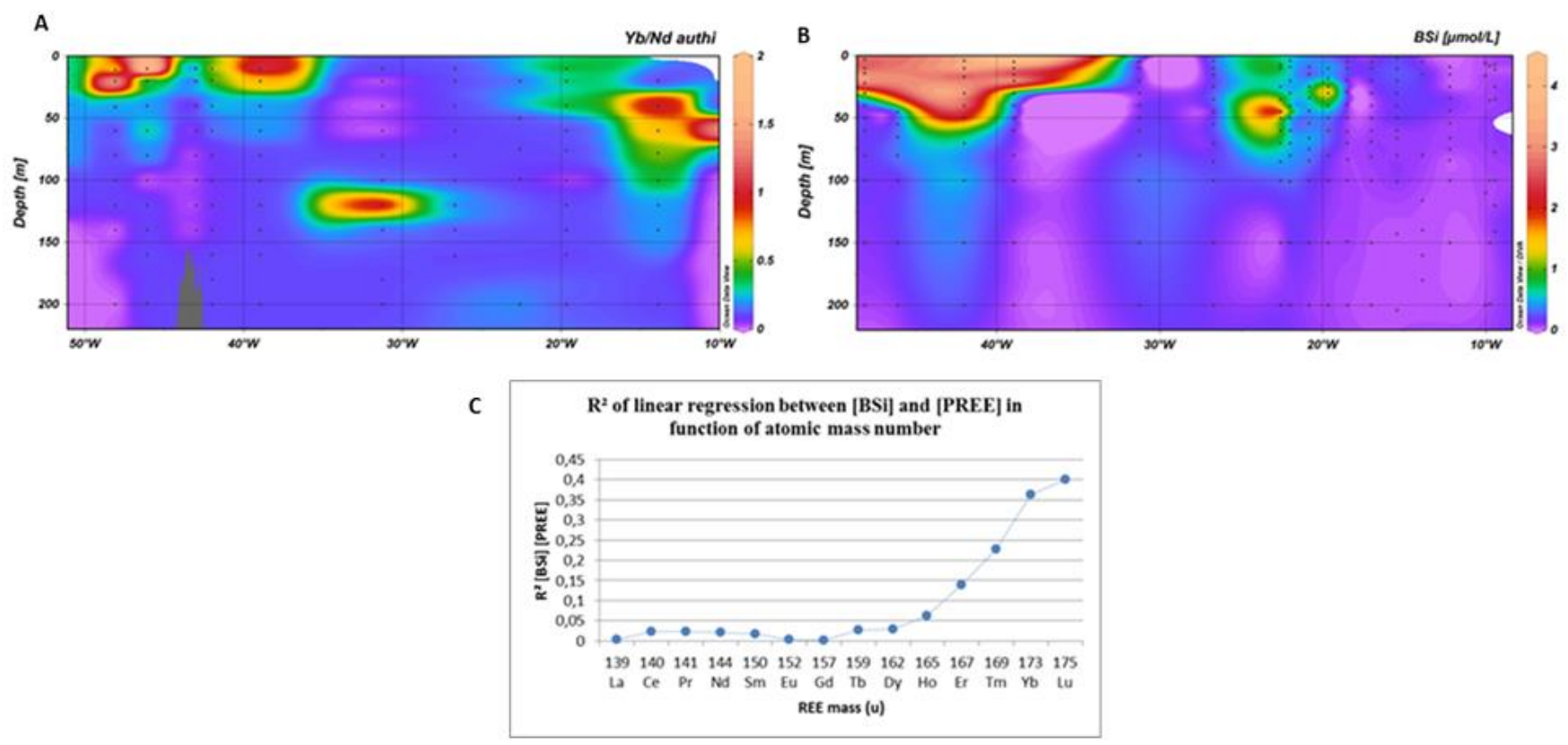

Figure S9: A. PYb/PNd ratio in the authigenic fraction B. Biogenic silica concentrations in the upper $200 \mathrm{~m}$, and C. Correlation coefficient between biogenic silica concentrations and PREE concentrations per REE. 